\title{
Effects of cold acclimation, cooling rate and heat stress on cold tolerance of the potato tuber moth Phthorimaea operculella (Lepidoptera: Gelechiidae)
}

\author{
Chamran HEMMATI, SAeid MOHARRAMiPOUR* and Ali Asghar TALEBI \\ Department of Entomology, Faculty of Agriculture, Tarbiat Modares University, P.O. Box, 14115-336 Tehran, Iran; \\ e-mails: moharami@modares.ac.ir; chamran.hemmati@gmail.com; talebia@modares.ac.ir
}

Key words. Lepidoptera, Gelechiidae, Phthorimaea operculella, freeze intolerant insects, lower lethal temperature, cold hardiness, cross resistant

\begin{abstract}
This study was carried out to investigate the effects of cold acclimation, cooling rate and heat stress on supercooling capacity and cold hardiness of the potato tuber moth (PTM), Phthorimaea operculella Zeller (Lepidoptera: Gelechiidae). Supercooling points (SCP) of first and last instar larvae, prepupae and pupae were $-21.8,-16.9,-18.9$ and $-18.0^{\circ} \mathrm{C}$, respectively. Cold acclimation (1-week at 0 and $5^{\circ} \mathrm{C}$ ) did not affect SCPs of acclimated last instar larvae, prepupae and pupae. $\mathrm{LT}_{50} \mathrm{~s}$ (lower lethal temperature for $50 \%$ mortality) for first and last instar larvae, prepupae and pupae were $-15.5,-12.4,-17.9$ and $-16.0^{\circ} \mathrm{C}$, respectively. Cold acclimation resulted in a significant decrease in mortality of all developmental stages. In addition, the mortality rates of the different developmental stages decreased with decrease in cooling rate. In addition, heat hardening (kept at $40^{\circ} \mathrm{C}$ for $2 \mathrm{~h}$ ) significantly reduced mortality of all developmental stages exposed to $\mathrm{LT}_{50}$ conditions, suggesting that heat hardening also affects cold tolerance. Results indicate that none of the stages could tolerate subzero temperatures below their SCPs, indicating that this species might be a chill tolerant insect. These adaptive responses may allow PTM to enhance its cold tolerance and colonize cold regions.
\end{abstract}

\section{INTRODUCTION}

One of the factors that accounts for the wide geographical distribution of insects is their ability to survive under a wide range of environmental conditions. In particular, cold may represent an important environmental obstacle for ectothermic species in most temperate and arctic regions. Based on their responses to freezing, insects are commonly categorized as either freeze tolerant or freeze intolerant and the latter has several sub-divisions: opportunistic, chill-susceptible, chill-tolerant, freeze avoiding (Lee, 2010). Several temperature-associated factors condition the successful survival over winter of insects, among which are the lowest temperature experienced by them, daily thermal variations and cooling rates associated with these variations, duration of exposure to chilling temperatures and the possibility of acclimation to mild temperatures (from 0 to $5^{\circ} \mathrm{C}$ ) (Kelty \& Lee, 2001; Sung et al., 2003). Insects display marked hardening and acclimation responses. The relationship between cold acclimation and cold tolerance is documented for different developmental stages of different arthropod species (Shintani \& Ishikawa, 2007; Slabber et al., 2007; Zheng et al., 2011; Khodayari et al., 2012). In addition, even very short pre-exposures to cold may increase thermal tolerance in insects (Qiang et al., 2008; Ju et al., 2011; Zheng et al., 2011). Finally, cross-tolerance is recorded in some insect species, suggesting that acclimation or hardening to one stress may also increase survival when subjected to other environmental stresses (Bubliy et al., 2012). For instance, in the sub-Antarctic caterpillar Pringleophaga marioni Viette, desiccation as well as high-temperature treatments result in an increase in survival when exposed to low temperatures (Sinclair \& Chown, 2003).

The duration of exposure to cold temperatures can greatly affect the survival of species due to the progressive loss of physiological homeostasis. Meanwhile, high mortality also occurs when organisms are exposed to abruptly decreasing temperatures (Terblanche et al., 2011). In this case, Rezende et al. (2011) and Santos et al. (2011) suggest that there are problems with assessing insect cold tolerance by slow thermal ramping as it increases the duration of exposure to cold, and thus, mortality may be overestimated. Conversely, other studies document that ramping assays are valid and ecologically relevant for assessing insect thermal tolerance (Terblanche et al., 2011; Overgaard et al., 2012). Positive relationships between cooling rate and mortality in larval and adult stages are documented for several insect species (Salt, 1966; Miller, 1978; Kelty \& Lee, 2001; Overgaard et al., 2012).

Insects that live in cold areas have developed a range of strategies such as cryoprotectant synthesis, membrane restructuring, up-regulation of stress-related genes (e.g. heat shock proteins), synthesis of antifreeze proteins and/or ice nucleating agents, inhibition of apoptotic cell death, Mitogen-activated protein (MAP) kinase signalling and calcium signalling (reviewed by Teets \& Denlinger, 2013).

The Potato Tuber moth (PTM), Phthorimaea operculella Zeller (Lepidoptera: Gelechiidae), is one of the most important potato pests because of its close relationship with this crop. PTM is a widespread pest of the Solanaceae including crops and weeds, but specifically potato, Solanum

\footnotetext{
* Corresponding author.
} 
tuberosum L. (Coll et al., 2000), and was introduced into Iran with infested potatoes in 1985. This species is now widely distributed in the temperate zone of Iran (Behdad, 2002; Golizadeh \& Zalucki, 2012). PTM is characterized by a high adaptability to daily and seasonal thermal variations and high reproductive potential (Briese, 1986; Herman et al., 2005). Early studies conducted by Langford in 1934 indicate that PTM can survive cold temperatures ranging from -11.6 to $-6.6^{\circ} \mathrm{C}$, but prolonged exposures to these temperatures are fatal for all developmental stages. Trivedi \& Rajagopal (1992) found that pupae are the most tolerant to cold temperatures; however, Langford \& Cory (1932) indicate that full-grown larvae appear to best able to survive exposure to low temperatures. Finally, Dŏgramaci et al. (2008) indicate that with the exception of the last (prepupal) instar larvae that are about to pupate and leave tubers before they freeze, most larvae remain inside tubers and thus are likely to be killed by frost during winter.

In a recent study, Kroschel et al. (2013) report that PTM now occurs in cold regions, indicating that PTM is able to survive cold temperatures. However, previous authors that investigated PTM cold tolerance neglected the importance of cold acclimation, heat hardening and ramp rates on mortality.

In the present study, we first report the $\mathrm{SCP}$ and $\mathrm{LT}_{50}$ values of different developmental stages of PTM. We aimed to confirm that cold acclimation and heat hardening can enhance cold tolerance of $1 \mathrm{st}$, last, prepupae and pupae of PTM and hypothesized that (1) there is a cross-tolerance between cold tolerance and heat hardening and (2) PTM is a chill tolerant species that can survive exposures to extremely low temperatures (up to $-25^{\circ} \mathrm{C}$ ). Also, we report that the slower the ramping rate the lower the mortality.

\section{MATERIAL AND METHODS}

\section{Insects}

100 adults of Phthorimaea operculella were originally collected from potato farms in Ardabil province $\left(24^{\circ} 38^{\prime} \mathrm{N}, 29^{\circ} 48^{\prime} \mathrm{E}\right.$, North Western part of Iran) in September 2011. Insects were maintained and reproduced for 6 months in a cage consisting of a clear cubic plexiglass container $(100 \times 50 \times 40 \mathrm{~cm})$ with one side removed and replaced by fine mesh gauze. The cages were kept under controlled conditions $\left(29 \pm 1{ }^{\circ} \mathrm{C}, 70 \pm 5 \% \mathrm{RH}\right.$ and $\left.16 \mathrm{~L}: 8 \mathrm{D}\right)$. The insects were grown on potato cultivar Agria.

\section{Determination of supercooling points}

The supercooling points of developmental stages $(n=20-25$ individual for each stage including 1st instar, last instar larvae, prepupae and pupae) were recorded using a thermocouple ( $\mathrm{NiCr}-$ Ni probe) connected to an automatic temperature recorder, Testo 177-T4 (Testo, Germany), so that the temperature could be recorded every $30 \mathrm{~s}$. The data were then read using Comsoft 3 Software. The specimens were attached to the thermocouple by adhesive tape and placed inside a programmable refrigerated chamber. The temperature was lowered from 30 to $-30^{\circ} \mathrm{C}$ at a rate of $0.5^{\circ} \mathrm{C}$. $\mathrm{min}^{-1}$. The temperature at which an abrupt temperature increase occurred, which corresponds to the liberation of the latent heat of freezing, is the SCP (Khani \& Moharramipour, 2011). After this measurement, all individuals were returned to $30^{\circ} \mathrm{C}$ and further assessed for survival after $24 \mathrm{~h}$.

\section{$\mathbf{L T}_{50}$ determination}

To determine the lower lethal temperature for $50 \%$ mortality $\left(\mathrm{LT}_{50}\right)$ of each developmental stage, potatoes were cut open and larvae removed. Insects were placed individually into a $15 \mathrm{ml}$ vials and put inside a programmable refrigerated test chamber, and the temperature lowered from $29^{\circ} \mathrm{C}$ to $-5,-8,-13,-16,-20$ or $-23 \pm 0.5^{\circ} \mathrm{C}$ at a rate of $0.5^{\circ} \mathrm{C} \cdot \mathrm{min}^{-1}$. Five replicates, each containing 10 specimens, were used for each experimental condition. The insects were kept for $2 \mathrm{~h}$ before the temperature was ramped up to $29^{\circ} \mathrm{C}$ at $0.5^{\circ} \mathrm{C} \cdot \mathrm{min}^{-1}$. After $24 \mathrm{~h}$, live and dead insects were counted and insects showing no movement were considered to be dead. To assess survival of pupae, we used forceps to stimulate them, if they moved their abdomen they were considered to be live (Khani \& Moharramipour, 2011).

\section{Effect of ramping rates on cold hardiness}

The effects of the cooling rate on the cold hardiness of the developmental stages (last instar larvae, prepupae and pupae) were examined ( 5 replicates of 10 insects for each thermal treatment and each developmental stage). Specimens were cooled from $29^{\circ} \mathrm{C}$ to the $\mathrm{LT}_{50}$ values of each developmental stage by direct transfers, or by cooling at rates of $0.5,0.1$ or $0.05^{\circ} \mathrm{C} \mathrm{min}{ }^{-1}$. After a $2 \mathrm{~h}$ exposure to the $\mathrm{LT}_{50}{ }^{\circ} \mathrm{C}$, insects were warmed up to $29^{\circ} \mathrm{C}$ at $0.5^{\circ} \mathrm{Cmin}^{-1}$ and maintained at this temperature in an environmental chamber for $24 \mathrm{~h}$ before assessing their survival.

\section{Cold acclimation capacities and cross-tolerance}

Potatoes containing larvae of different developmental stages were placed at $0^{\circ} \mathrm{C}$ and $5^{\circ} \mathrm{C}$ for one week. The larvae were then separated and put into vials ( 5 replicates of 10 insects for each treatment) incubated inside a programmable refrigerated test chamber; the temperature of which was lowered from the acclimation temperature $\left(5\right.$ or $\left.0^{\circ} \mathrm{C}\right)$ to the $\mathrm{LT}_{50}$ at a rate of $0.5^{\circ} \mathrm{C}$. $\mathrm{min}^{-1}$. After a $2 \mathrm{~h}$ exposure at the $\mathrm{LT}_{50}$ temperature, insects were returned to $29^{\circ} \mathrm{C}$ at $0.5^{\circ} \mathrm{Cmin}^{-1}$ and maintained at this temperature for $24 \mathrm{~h}$ before assessing their survival.

The existence of cross-tolerance between heat and cold responses was determined using last instar larvae, prepupae and pupae. The developmental stages were separated from potatoes and placed into vials ( 5 replicates of 10 insects for each thermal treatment and for each developmental stage) and directly transferred to a refrigerated chamber set to $40^{\circ} \mathrm{C}$. After a $2 \mathrm{~h}$ exposure to this temperature, the insects were cooled to $\mathrm{LT}_{50}$ at $0.5,0.1$ or $0.05^{\circ} \mathrm{C} /$ min, or were directly transferred to $\mathrm{LT}_{50}$ (direct treatment). All of the samples were kept for $2 \mathrm{~h}$ at the $\mathrm{LT}_{50}$ before they were warmed up to $29^{\circ} \mathrm{C}$ at the same rate as they were cooled down. After $24 \mathrm{~h}$, live or dead insects were assessed. All treatments are as illustrated in Fig. 1.

\section{Statistical analysis}

To determine the $\mathrm{LT}_{50}$ value of the different developmental stages, binary logistic regressions were used to calculate the temperature at which 50\% mortality occurred (Saeidi et al., 2012).

Mean SCPs and mortality of the different specimens under cold acclimation and different cooling rates were compared using a one-way analysis of variance (ANOVA), followed by Tukey's test for multiple comparisons $(\mathrm{P}<0.05)$. Data were initially normalized (arcsine transformation) before subjecting them to ANOVA. Differences between treatments involving heat stress and cooling rate were compared using independent student's t-tests. The relationship between cooling rate and mortality rate was simulated using linear regression analysis (Pearson correlation). 


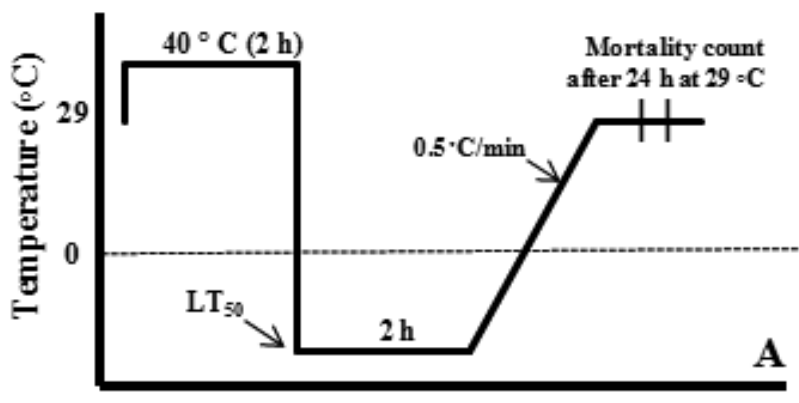

Time

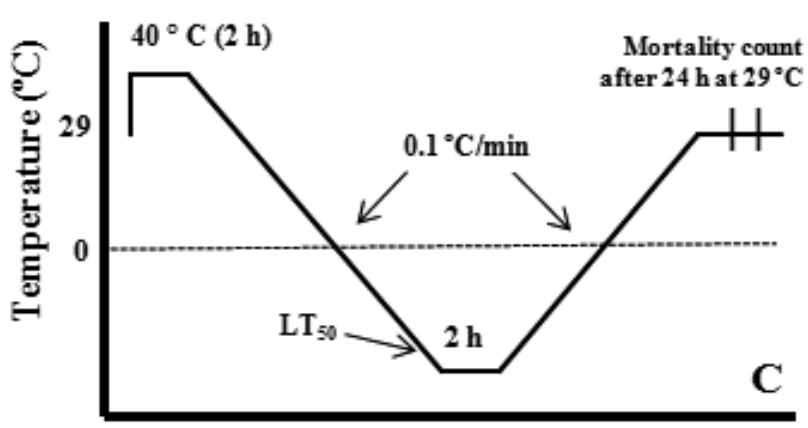

Time

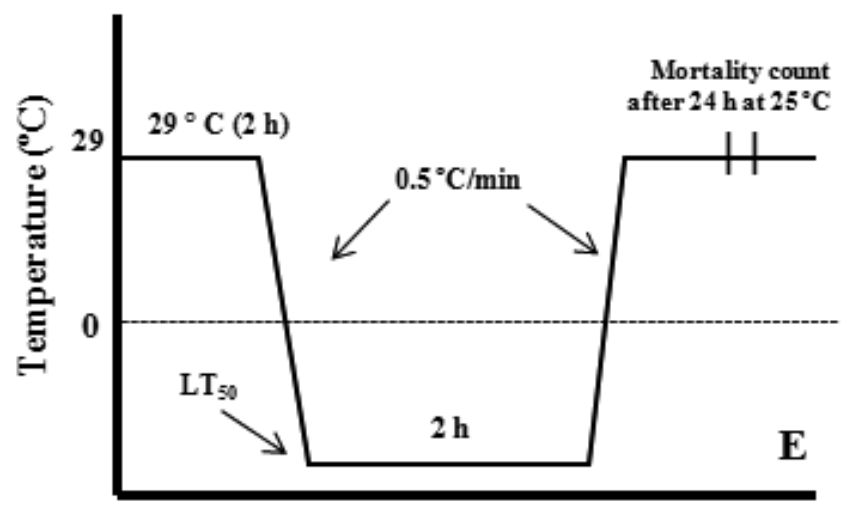

Time

\section{RESULTS}

\section{Supercooling points and $\mathbf{L T}_{\mathbf{5 0}}$}

SCP values of the different developmental stages differed significantly $\left(\mathrm{P} \leq 0.001 ; \mathrm{F}_{3,76}: 5.93\right)$, with the first instar exhibiting the lowest SCP value and the last instar larvae the highest (Table 1). Cold acclimation (one-week at 0 or $\left.5^{\circ} \mathrm{C}\right)$ had no effect on SCPs of last instar larvae, $\left(\mathrm{F}_{2,61}\right.$ $=0.774 ; \mathrm{P}=0.46)$, prepupae $\left(\mathrm{F}_{2.57}=1.32 ; \mathrm{P}=0.273\right)$ and pupae $\left(\mathrm{F}_{2,57}=2.63 ; \mathrm{P}=0.08\right)$ (Table 1).

The $\mathrm{LT}_{50}$ values of $1^{\text {st }}$ and last instar larvae, prepupae and pupae were $-15.5^{\circ} \mathrm{C}$ [95\% confidence limits $(95 \%$ $\left.\mathrm{CL}):-15.7,15.1^{\circ} \mathrm{C}\right],-12.4^{\circ} \mathrm{C}\left(95 \% \mathrm{CL}:-12.6,-11.9^{\circ} \mathrm{C}\right)$, $-17.9^{\circ} \mathrm{C}\left(95 \% \mathrm{CL}:-18.1,-17.5^{\circ} \mathrm{C}\right)$ and $-16.0^{\circ} \mathrm{C}(95 \% \mathrm{CL}$ : $\left.-16.0,-16.1{ }^{\circ} \mathrm{C}\right)$, respectively. The higher thermal tolerance of prepupae was confirmed by their greater ability to survive exposures to $-20^{\circ} \mathrm{C}$, with survival as high as $41 \%$, whereas none of the other stages survived at this temperature (Fig. 2).

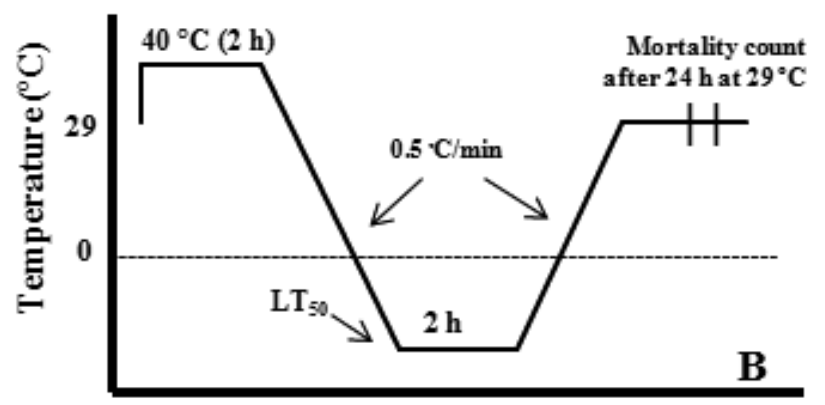

Time

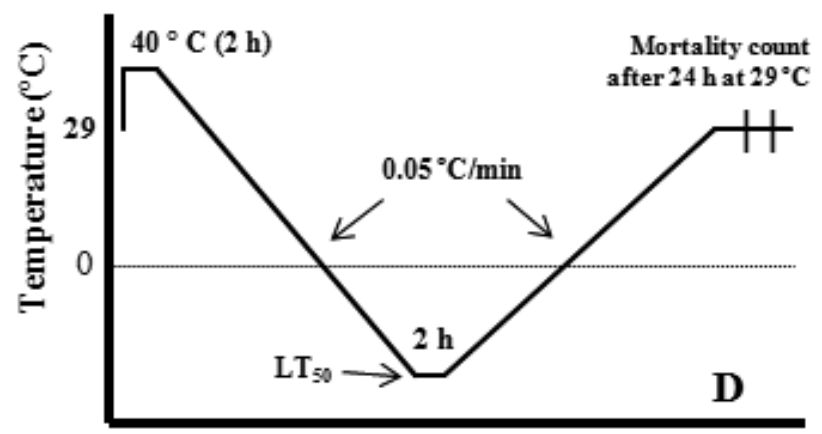

Time

Fig. 1. Experimental protocols for heat stress treatments of the different developmental stages starting from $29^{\circ} \mathrm{C}$ and then increasing up to $40^{\circ} \mathrm{C}$ directly $(2 \mathrm{~h})$, then cooling down to $\mathrm{LT}_{50}$ : (A) direct transfer to $\mathrm{LT}_{50}$ for $2 \mathrm{~h}$; (B) cooling rate of $0.5^{\circ} \mathrm{C} . \mathrm{min}^{-1}$; (C) cooling rate of $0.1^{\circ} \mathrm{C} \cdot \mathrm{min}^{-1}$, (D) cooling rate of $0.05^{\circ} \mathrm{C} \cdot \mathrm{min}^{-1}$ and (E) control. The $\mathrm{LT}_{50}$ values used for $1^{\text {st }}$ and last instar larvae, prepupae and pupae were $-15.5,-12.4,-17.9$ and $-16.0^{\circ} \mathrm{C}$, respectively.

\section{Cold acclimation capacities}

Cold acclimation for one week at 0 and $5^{\circ} \mathrm{C}$ significantly decreased the mortality of $1^{\text {st }}$ instar larvae $\left(\mathrm{F}_{2,12}=13.23 ; \mathrm{P}\right.$ $<0.01)$, prepupae $\left(\mathrm{F}_{2,12}=8.04 ; \mathrm{P}<0.001\right)$ and pupae $\left(\mathrm{F}_{2,12}\right.$ $=15.57 ; \mathrm{P}<0.001$ ) cooled down to $\mathrm{LT}_{50}$. The mortality of first instar larvae decreased from $46 \%$ in the control to $20 \%$ and $26 \%$ at 5 and $0{ }^{\circ} \mathrm{C}$, respectively $\left(\mathrm{F}_{2,12}=13.23 ; \mathrm{P}\right.$ $<0.01)$. No significant difference was recorded between the survival of acclimated and non-acclimated last instar larvae $\left(\mathrm{F}_{2,12}=2.64 ; \mathrm{P}=0.112\right.$, Fig. 3$)$.

Effect of the cooling rate on the cold hardiness of the developmental stages

The slowest cooling rate resulted in the lowest mortality: fewer first instar larvae cooled at a rate of 0.05 and $0.1^{\circ} \mathrm{C}$. $\mathrm{min}^{-1}$ died than when cooled at $0.5^{\circ} \mathrm{C} \cdot \mathrm{min}^{-1}$ or directly transferred to $\mathrm{LT}_{50}\left(\mathrm{~F}_{3,16}=46.54 ; \mathrm{P}<0.01\right)$. Similar results were recorded for last instar larvae $\left(\mathrm{F}_{3,16}=27.89 ; \mathrm{P}<0.01\right.$, prepupae $\left(\mathrm{F}_{3,16}=22.15 ; \mathrm{P}<0.01\right)$ and pupae $\left(\mathrm{F}_{3,16}=8.81 ; \mathrm{P}\right.$ $<0.01$ ) (Table 2). 


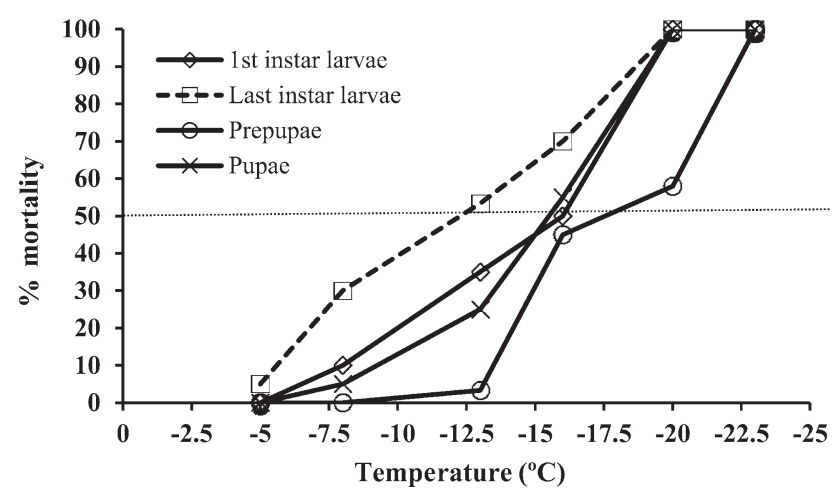

Fig. 2. Percentage mortality of $1^{\text {st }}$ and last instars larvae, prepupae and pupae of Phthorimaea operculella at different subzero temperatures after a cooling rate of $0.5^{\circ} \mathrm{C} . \mathrm{min}^{-1}$ and an exposure of $2 \mathrm{~h}$.

There was a positive correlation between cooling rate and mortality in all developmental stages except the pupal stage $\left(1^{\text {st }}\right.$ instar larvae: $\mathrm{r}=0.83, \mathrm{P}=0.001$; last instar larvae: $\mathrm{r}=0.66, \mathrm{P}=0.006$; prepupae: $\mathrm{r}=0.62, \mathrm{P}=0.014$ and pupae: $\mathrm{r}=0.28, \mathrm{P}=0.30$ ).

\section{Cross-tolerance between heat hardening and cold tolerance}

There is a cross-tolerance between heat hardening and cold tolerance in this pest. When insects were held at $40^{\circ} \mathrm{C}$ for $2 \mathrm{~h}$, the mortality of all developmental stages decreased significantly when exposed to subzero temperatures (their $\mathrm{LT}_{50}$ ). In addition, cold hardiness was enhanced by a slow cooling rate. When insects were transferred from $29^{\circ} \mathrm{C}$ to $\mathrm{LT}_{50}$ directly, the first instar larvae suffered the highest mortality. As shown in Fig. 4, no significant differences were detected between heat stress treatment and control by cooling rates of 0.1 and $0.05^{\circ} \mathrm{C} \cdot \mathrm{min}^{-1}$. Compared with the controls mortality was significantly higher when cooling rate was $0.5^{\circ} \mathrm{C} \cdot \mathrm{min}^{-1}$. In the last instar larvae, differences between heat stress treatments and control was much greater than in all other stages. In all treatments except cooling rate of $0.05^{\circ} \mathrm{C} \cdot \mathrm{min}^{-1}$, heat stress enhanced cold hardiness of last instar larvae. The lowest mortality was recorded for the prepupal stage in heat stress conditions. There were significant differences between heat stress and control treatments. Significant decrease in mortality was recorded also in the pupal stage.

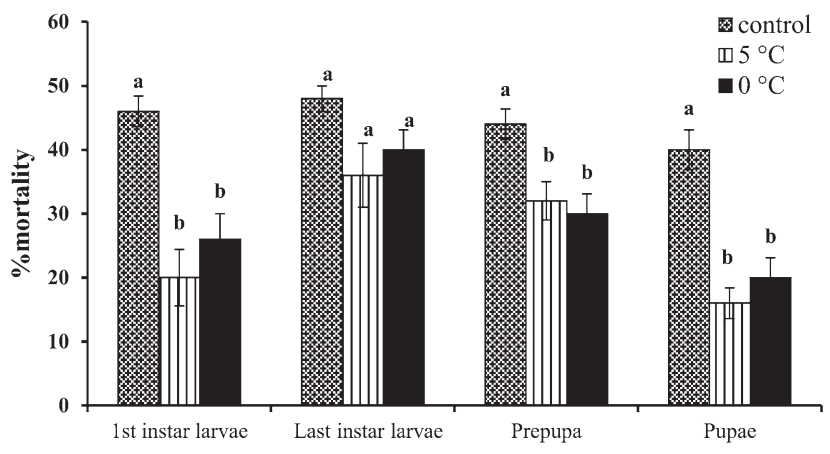

Fig. 3. Effects of cold acclimation at 5 and $0^{\circ} \mathrm{C}$ for one week on mortality of 1 st and final instar larvae, prepupae and pupae of Phthorimaea operculella. Values (mean \pm SE) followed by the same letters are not significantly different (Tukey's test, $\mathrm{P}<0.05$ ).

\section{DISCUSSION}

Our studies showed that the SCPs of last instar larvae, prepupae and pupa were much higher than those of first instar larvae $\left(-21^{\circ} \mathrm{C}\right)$ and eggs $\left(-25.8^{\circ} \mathrm{C}\right.$, unpubl. data). As these results are similar to those of previous studies on other insects, this may be attributed to the small size of eggs and first instar larvae (Denlinger \& Lee, 1998; Zheng et al., 2011), which usually have an elevated supercooling capacity (Angell, 1982; Somme, 1982). SCP and $\mathrm{LT}_{50}$ values of last instar larvae were higher than those of all other stages. A possible explanation of this might be that the last instar larvae are a feeding stage. It is well known from a range of species that gut contents act as an ice nucleating agent, which can increase the SCP values (Lee et al., 1996; Chown \& Nicolson, 2004). In addition, Boardman et al. (2012) demonstrate that fasting larvae of Thaumatotibia leucotreta (Meyrick) are more tolerant than those that are fed.

Concerning the supercooling ability of PTM, no significant differences were recorded when last instar larvae, prepupae and pupae of PTM were acclimated at 0 and $5^{\circ} \mathrm{C}$ for one week. The absence of a beneficial effect of acclimation on SCP, which increased survival at non-freezing temperatures, is not uncommon. It is reported that the accumulation of polyols with a cryoprotective role may not affect the SCP value (Kostal et al., 2001). These findings accord with those of several other studies done on Specicryptopygus anarcticus Willem (Cannon, 1988), Diatraea grandiosella Dyar (Popham et al., 1991) and Lobesia botrana Denis \& Schiffermuller (Andreadis et al., 2005), which do

TABLE 1. Effects of cold acclimation on supercooling point (SCP) of the different developmental stages of PTM.

\begin{tabular}{lcccc}
\hline \multirow{2}{*}{ Treatment } & \multicolumn{4}{c}{ Mean SCP $\pm \mathrm{SE}\left({ }^{\circ} \mathrm{C}\right)^{1}$} \\
\cline { 2 - 5 } & 1st instar larvae & Last instar larvae & Prepupae & Pupae \\
\hline Control & $-21.8 \pm 0.84^{\mathrm{a}}$ & $-16.9 \pm 1.08^{\mathrm{c}}$ & $-18.9 \pm 0.68^{\mathrm{b}}$ & $-18.0 \pm 0.81^{\mathrm{b}}$ \\
$\mathrm{CA} 5$ & $\mathrm{ND}$ & $-16.1 \pm 1.01$ & $-18.5 \pm 0.78$ & $-18.2 \pm 0.84$ \\
CA0 & $\mathrm{ND}$ & $-15.4 \pm 0.92$ & $-19.8 \pm 0.49$ & $-19.2 \pm 1.20$ \\
F-value & & $\mathrm{F}_{2,61}=0.774$ & $\mathrm{~F}_{2,57}=1.32$ & $\mathrm{~F}_{2,57}=2.63$ \\
P-value & & 0.46 & 0.27 & 0.08 \\
\hline
\end{tabular}

CA5 - Cold acclimation at $5^{\circ} \mathrm{C}$ for 1 week; CA0 - Cold acclimation at $0^{\circ} \mathrm{C}$ for 1 week. ${ }^{1}$ There were no significant differences for any of the developmental stages in the different thermal treatments $(\mathrm{P}>0.05)$ but the values did differ significantly from that of the control $\mathrm{SCP}$ in all developmental stages $\left(\mathrm{F}_{3,76}: 5.93 ; \mathrm{P} \leq 0.001\right)$. ND - Not detected. 

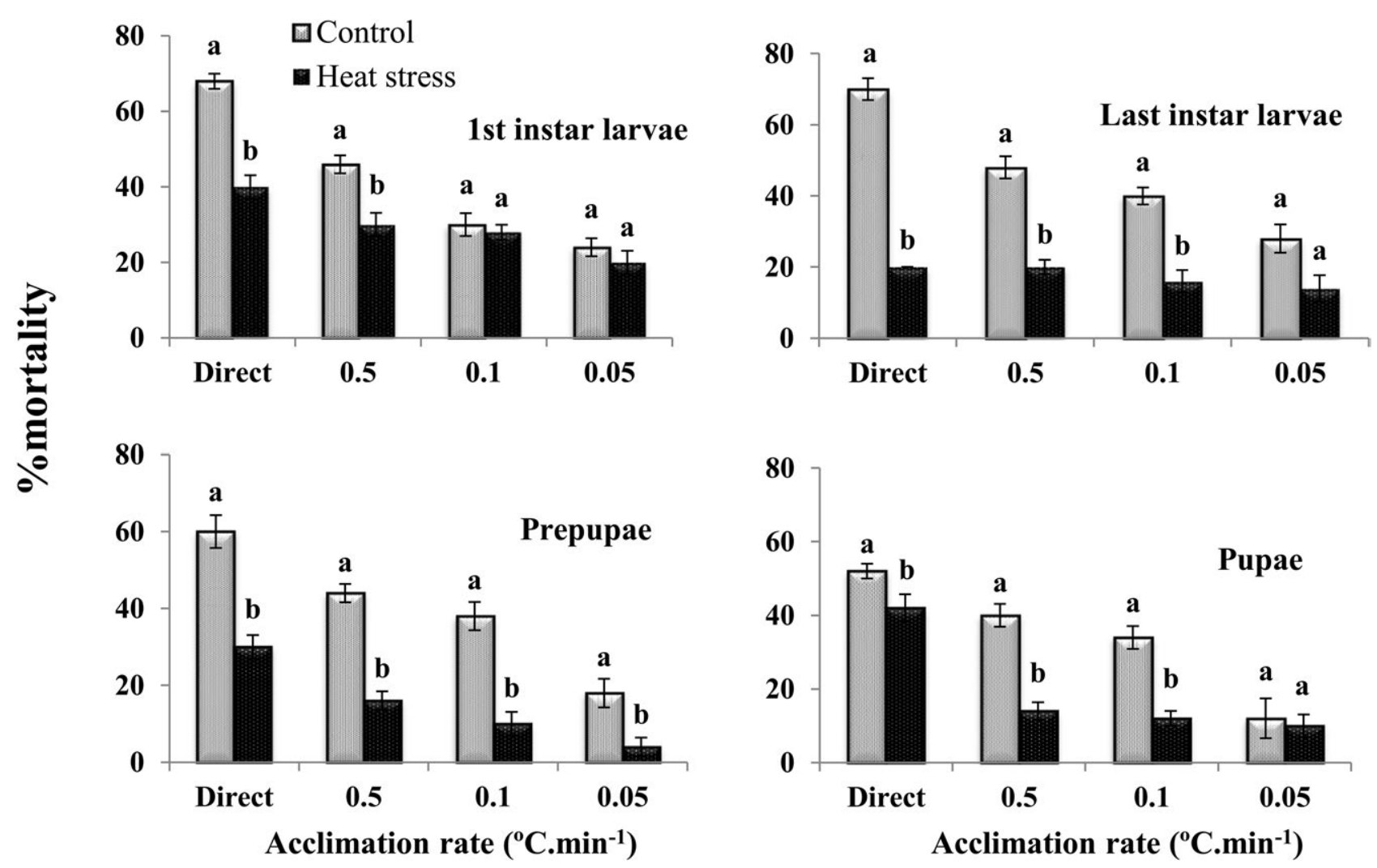

Fig. 4. Effect of heat stress and cooling rate on the mortality $( \pm \mathrm{SE})$ of $1^{\text {st }}$ and final instar larvae, prepupae and pupae of Phthorimaea operculella. Heat stress: held at $40^{\circ} \mathrm{C}$ for $2 \mathrm{~h}$; Control: from $29^{\circ} \mathrm{C}$ to $\mathrm{LT}_{50}$ with cooling rate of $0.5^{\circ} \mathrm{C} \cdot \mathrm{min}^{-1}$. (See details in Fig. 1.)

not record changes in SCP values when these arthropods were cold acclimated. It is known that low temperatures $\left(0\right.$ to $\left.5^{\circ} \mathrm{C}\right)$ may trigger the production and accumulation of cryoprotectant substances (Baust, 1973; Li et al., 2002; Ishiguro et al., 2007). Although we have no biochemical data for PTM, in other species, (Khani et al., 2007; Atapour et al., 2011) the enhanced survival at subzero temperatures are due to many factors such as increase in hemolymph osmolarity by partial dehydration, changes in membrane composition to adjust fluidity, the absence of potential icenucleating agents or the accumulation of cryoprotectants and other antifreeze elements, or both (Somme, 1982; Lee et al., 1996).

Langford (1934) report that PTM survive temperatures ranging from -6.6 to $-11.6^{\circ} \mathrm{C}$, but prolonged exposure to these temperatures are apparently lethal for all development stages. Our findings indicate that prepupae are more tolerant than other stages, which is consistent with the results of Trivedi \& Rajagopal (1992). Indeed, in our study, all first instar larvae, last instar larvae and pupae died at $-20^{\circ} \mathrm{C}$, but $41 \%$ of the prepupae survived at this temperature.

Our results indicate that none of the stages could tolerate subzero temperatures below their SCPs. According to Bale's classification (1996), species with low SCPs (typically -20 to $-30^{\circ} \mathrm{C}$ ) and a high level of cold tolerance are freeze-intolerant, characterized by high mortalities when exposed to temperatures above their SCPs. Thus, it can be concluded that PTM exhibits freeze intolerance according to Bale's classification and may be a chill tolerant insect.

It is well known that organisms increase their survival and resistance to extreme temperatures after prior exposure to non-lethal low or high temperatures (Hoffmann, 1995; Wang et al., 2010). Our results indicate that acclimation

TABLE 2. Effect of cooling rate on cold tolerance of developmental stages of PTM.

\begin{tabular}{|c|c|c|c|c|}
\hline \multirow{2}{*}{$\begin{array}{l}\text { Cooling rate } \\
\left({ }^{\circ} \mathrm{C} \cdot \mathrm{min}^{-1}\right)\end{array}$} & \multicolumn{4}{|c|}{$\%$ mortality $\pm \mathrm{SE}$} \\
\hline & 1st instar larvae & Last instar larvae & Prepupae & Pupae \\
\hline Direct $^{1}$ & $68.0 \pm 2.0^{\mathrm{a}}$ & $70.0 \pm 3.1^{\mathrm{a}}$ & $60.0 \pm 4.4^{\mathrm{a}}$ & $58.0 \pm 2.0^{\mathrm{a}}$ \\
\hline $0.5^{2}$ & $46.0 \pm 2.4^{b}$ & $48.0 \pm 2.0^{\mathrm{b}}$ & $44.0 \pm 2.4^{\mathrm{ab}}$ & $40.0 \pm 3.1^{\mathrm{ab}}$ \\
\hline 0.1 & $30.0 \pm 3.0^{\mathrm{c}}$ & $40.0 \pm 3.1^{\mathrm{b}}$ & $38.0 \pm 3.7^{\mathrm{b}}$ & $34.0 \pm 3.2^{\mathrm{b}}$ \\
\hline 0.05 & $24.0 \pm 2.4^{\mathrm{c}}$ & $28.0 \pm 3.7^{\mathrm{c}}$ & $18.0 \pm 3.7^{\mathrm{c}}$ & $30.0 \pm 5.4^{b}$ \\
\hline $\mathrm{F}_{212}$ & 46.54 & 27.89 & 22.15 & 8.81 \\
\hline P-value & $<0.001$ & $<0.001$ & $<0.01$ & $<0.01$ \\
\hline
\end{tabular}

${ }^{1}$ From $29^{\circ} \mathrm{C}$ to $\mathrm{LT}_{50}$ directly and held for $2 \mathrm{~h} .{ }^{2}$ From $29^{\circ} \mathrm{C}$ to $\mathrm{LT}_{50}$ of different developmental stages with different rates then, held at $\mathrm{LT}_{50}$ for $2 \mathrm{~h}$. Then, they were warmed up to $29^{\circ} \mathrm{C}$. Numbers of dead and live insects were assessed after $24 \mathrm{~h}$. Means followed by the same letters within a column are not significantly different (Tukey's test, $\mathrm{P}<0.05$ ). 
at 0 and $5^{\circ} \mathrm{C}$ for one week decreased mortality of all the developmental stages of PTM. Further studies should determine if acclimated specimens of the PTM have higher levels of low molecular weight polyols, sugars or amino acids; glycerol, sorbitol, trehalose, sucrose, proline and alanine are the most commonly reported in several other insect species (Storey \& Storey, 1988).

Several other studies have revealed a tight negative relationship between mortality and cooling rate (Kelty \& Lee, 1999; Powell \& Bale, 2004; Terblanche et al., 2011; Overgaard et al., 2012). The use of thermal ramping was recently criticised by Rezende et al. (2011) and Santos et al. (2011), who argue that estimates of thermo-tolerance obtained from ramping procedures confounds the simultaneous (and unwanted) effect of starvation and dehydration stress. These authors emphasize that slow thermal ramping is problematic as it increases the length of time organisms are exposed to cold temperatures. The models presented by Rezende et al. (2011) and Santos et al. (2011) therefore predict that water loss and energy expenditure affect the "true" thermal tolerance of the insects. However the conclusions of Rezende et al. (2011) and Santos et al. (2011) are challenged by Terblanche et al. (2011) and Overgaard et al. (2012) in a comprehensive review. They conclude that ramping assays are valid and ecologically relevant procedures to assess thermal tolerance of $D$. melanogaster and similar small-sized arthropods. Finally, gradual exposure to increasing or decreasing temperatures allows the development of physiological mechanisms (water loss, starvation and effect of energy expenditure) that enhance cold survival (Overgaard et al., 2011). Conversely, these physiological adjustments occur too slowly to affect the outcome when animals are exposed abruptly to extreme temperatures (Terblanche et al., 2011).

Variations in cooling rates can affect insects' thermal limits (Terblanche et al., 2011), as slow ramping reduces the risk of cold shock and may enable physiological adjustments during changes in experimental conditions. In addition to high mortality, low temperature can also cause cold injury, which is comprised of non-freezing and freezing injuries (Lee, 2010). Non-freezing injury usually is divided into two categories: (1) direct chilling injury (Quinn, 1985) and (2) indirect chilling injury (Morris \& Watson, 1984). High mortality in the direct treatment may be due to direct chilling injury.

When all developmental stages of PTM were kept at $40^{\circ} \mathrm{C}$ for $2 \mathrm{~h}$, mortality decreased significantly. Acclimation or hardening to one stress in arthropods can confer increased resistance to other stresses, the so-called crosstolerance (Bubliy et al., 2012). Our findings indicate that there is cross-tolerance between heat hardening and cold tolerance. Sinclair \& Chown (2003) indicate that in $P$. marioni, desiccation as well as high-temperature treatments result in an increase in larval survival at low temperatures. Conversely, Bubliy et al. (2012) report that heat hardening has no effect on cold tolerance of Drosophilla melanogaster. A possible explanation for a decrease in mortality after heat hardening is that organisms exposed to high temperatures usually loose water and this can result in osmotic stress at the cellular level. Desiccation, extracellular freezing, chilling and cryoprotective dehydration all decrease the volume of haemolymph and thus contribute to an increase in haemolymph osmolarity.

Another possible explanation for this is that, reduction in mortality might be due to synthesis of heat shock proteins in $P$. operculella. When organisms are exposed to a variety of stresses such as heat, cold, toxic gases and various substances, they synthesize a small set of proteins called heat shock proteins (HSPs), which are able to increase cold hardiness of animals (Sorensen et al., 2003). It is known that HSP can increase cold hardiness in many insects (Chen et al., 1987; Denlinger et al., 1991; Krebs \& Feder, 1998).

Our results confirm that $P$. operculella is a freezing intolerant species and that cold acclimation increases the level of cold hardiness of this species. Slow cooling rate and heat stress had significant effects on the cold hardiness of all developmental stages. As this insect can tolerate subzero temperatures near to its SCPs, it can be classified as a chill tolerant insect. Our findings indicate that PTM has the potential to establish in regions with severe winters. Further investigations are needed to study the physiological mechanisms such as the actual roles of sugar, polyols and heat shock proteins.

ACKNOWLEDGEMENT. We would like to thank D. Renault for his constructive comments and helpful advice that enabled us to identify and correct interpretations.

\section{REFERENCES}

Andreadis S.S., Milonas G.P. \& Savopoulou-Soultani M. 2005: Cold hardiness of diapausing and non-diapausing pupae of the European grapevine moth, Lobesia botrana. - Entomol. Exp. Appl. 117: 113-118.

Angell C.A. 1982: Supercooled water. In Franks F. (ed.): Water: A Comprehensive Treatise. Plenum, New York, pp. 1-81.

Atapour M., Moharramipour S. \& Barzegar M. 2011: Changes of cryoprotectants in overwintering larvae of beet armyworm, Spodoptera exigua (Lep.: Noctuidae). — J. Entomol. Soc. Iran 31: 33-50.

BALE J.S. 1996: Insect cold hardiness: a matter of life and death. — Eur. J. Entomol. 93: 369-382.

BAust J.G. 1973: Mechanisms of cryoprotection in freezing tolerant animal systems. - Cryobiology 10: 197-205.

BEHDAD E. 2002: Introductory Entomology and Important Plant Pests in Iran. Yadbud Press, Isfahan, 840 pp. [in Persian].

Boardman L., Tim G. \& Terblanche J.S. 2012: False codling moth Thaumatotibia leucotreta (Lepidoptera, Tortricidae) larvae are chill-susceptible. — Insect Sci. 19: 315-328.

BRIESE D.T. 1986: Geographic variability in demographic performance of the potato moth, Phthorimaea operculella Zell. Aust. Bull. Entomol. Res. 76: 719-726.

Bubliy O.A., Kristensen T.N., Kellermann V. \& Loeschcke V. 2012: Plastic responses to four environmental stresses and cross-resistance in a laboratory population of Drosophila melanogaster. — Funct. Ecol. 26: 245-253.

CANNON R.J. 1988: Diet and acclimation effects on the cold tolerance and survival of an Antarctic springtail. - Br. Antarct. Surv. Bull. 71: 19-30. 
Chen C.P., Denlinger D.L. \& Lee R.E. JR. 1987: Cold-shock injury and rapid cold hardening in the flesh fly Sarcophaga crassipalpis. — Physiol. Zool. 60: 297-304.

Chown S.L. \& Nicolson S.W. 2004: Insect Physiological Ecology: Mechanisms and Patterns. Oxford University Press, Oxford, $243 \mathrm{pp}$.

Coll M., Gavish S. \& Dori I. 2000: Population biology of the potato tuber moth, Phthorimaea opercuella (Lepidoptera: Gelechiidae) in two potato cropping systems in Israel. — Bull. Entomol. Res. 90: 309-315.

Denlinger D.L. \& Lee R.E. 1998: Physiology of cold sensitivity. In Hallman G.J. \& Denlinger D.L. (eds): Temperature Sensitivity in Insects and Application in Integrated Pest Management. Westview Press, Boulder, pp. 55-95.

Denlinger D.L., Joplin K.H., Chen C.P. \& Lee R.E. 1991: Cold shock and heat shock. In Lee R.E. Jr. \& Denlinger D.L. (eds): Insects at Low Temperature. Chapmann and Hall, New York, pp. 131-148.

Dŏgramaci M., Rondon S.I. \& DeBano S.J. 2008: The effect of soil depth and exposure to winter conditions on survival of the potato tuberworm Phthorimaea operculella (Lepidoptera: Gelechiidae). - Entomol. Exp. Appl. 129: 332-339.

GolizADEH A. \& ZaluCKI M.P. 2012: Estimating temperaturedependent developmental rates of potato tuberworm, Phthorimaea operculella (Lepidoptera: Gelechiidae). — Insect Sci. 19: $609-620$.

Herman T.J.B., Clearwater J.R. \& Triggs C.M. 2005: Impact of pheromone trap design, placement and pheromone blend on catch of potato tuber moth. - N. Z. Plant Prot. 58: 219-223.

HoffMAnN A.A. 1995: Acclimation: increasing survival at a cost. - Trends Ecol. Evol. 10: 1-2.

Ishiguro S., Li Y., Nakano K., Tsumuki H. \& Goto M. 2007: Seasonal changes in glycerol content and cold hardiness in two ecotypes of the rice stem borer, Chilo suppressalis, exposed to the environment in the Shonai district, Japan. - J. Insect Physiol. 53: 392-397.

Ju R., XIAO Y. \& Li B. 2011: Rapid cold hardening increases cold and chilling tolerances more than acclimation in the adults of the sycamore lace bug, Corythucha ciliata (Say) (Hemiptera: Tingidae). - J. Insect Physiol. 57: 1577-1582.

Kelty J.D. \& Lee R.E. JR. 1999: Induction of rapid cold hardening by cooling at ecologically relevant rates in Drosophila melanogaster. - J. Insect Physiol. 45: 719-726.

Kelty J.D. \& Lee R.E. JR. 2001: Rapid cold-hardening of Drosophila melanogaster (Diptera: Drosophilidae) during ecologically based thermoperiodic cycles. - J. Exp. Biol. 204: 16591666.

Khani A. \& Moharamipour S. 2011: Cold hardiness and supercooling capacity in the overwintering larvae of the codling moth, Cydia pomonella. - J. Insect Sci. 10: 12 pp.

Khani A., Moharramipour S. \& Barzegar M. 2007: Cold tolerance and trehalose accumulation in overwintering larvae of the codling moth, Cydia pomonella (Lepidoptera: Tortricidae). Eur. J. Entomol. 104: 385-392.

Khodayari S., Moharramipour S., Kamali K., Jalali JaVaran M. \& Renault D. 2012: Effect of acclimation and diapauses on thermal tolerance of the two-spotted spider mite Tetranychus urticae. - J. Therm. Biol. 37: 419-423.

Kostal V., Slachta M. \& SimeK P. 2001: Cryoprotective role of polyols independent of the increase in supercooling capacity in diapausing adult of Pyrhocoris apeterus (Heteroptera: Pyrhocoridae). - Comp. Biochem. Physiol. (B) 130: 365-374.

Krebs R.A. \& Feder M.E. 1998: Hsp70 and larval thermotolerance in Drosophila melanogaster: how much is enough and when is more too much? - J. Insect Physiol. 44: 1091-1101.
Kroschel J., Sporleder M., Tonnang H.E.Z., Juarez H., Carhuapoma P., Gonzales J.C. \& Simon R. 2013: Predicting climatechange-caused changes in global temperature on potato tuber moth Phthorimaea operculella (Zeller) distribution and abundance using phenology modeling and GIS mapping. - Agric. Forest Meteor. 170: 227-241.

LANGFORD G.S. 1934: Winter survival of the potato tuber moth, Phthorimaea operculella Zeller. - J. Econ. Entomol. 27: 210-213.

LANGFORD G.S. \& CORY E.N. 1932: Observations on the potato tuber moth. - J. Econ. Entomol. 25: 625-634.

LEE R.E. JR. 2010: A primer on insect cold-tolerance. In Denlinger D.L. \& Lee R.E. Jr. (eds): Low Temperature Biology of Insects. Cambridge University, Cambridge, pp. 3-34.

Lee R.E. JR., Strong-Gunderson J.M., Lee M.R., Grove K.S. \& RigA T.J. 1991: Isolation of ice nucleating active bacteria from insects. - J. Exp. Zool. 257: 124-127.

Lee R.E. JR., Costanzo J.P. \& Mugnano J.A. 1996: Regulation of supercooling and ice nucleation in insects. - Eur. J. Entomol. 93: $405-418$.

Li Y., Goto M., Ding L. \& Tsumuki H. 2002: Diapause development and acclimation regulating enzymes associated with glycerol synthesis in the Shonai ecotype of the rice stem borer larva, Chilo suppressalis Walker. - J. Insect Physiol. 48: 303-310.

MiLLER L.K. 1978: Freezing tolerance in relation to cooling rate in an adult insect. - Cryobiology 15: 345-349.

MorRIs G.J. \& Watson P.F. 1984: Cold shock injury a comprehensive bibliography. - CryoLetters 5: 352-372.

Overgaard J., Kristensen T.N., Mitchell K.A. \& Hoffmann A.A. 2011: Thermal tolerance in widespread and tropical Drosophila species: Does phenotypic plasticity increase with latitude? - Am. Nat. 178: 80-96.

Overgaard J., Kristensen T.N. \& Sørensen J.G. 2012: Validity of thermal ramping assays used to assess thermal tolerance in arthropods. - PLoS ONE 7(3): e32758.

Popham H.J.R., George M.F. \& Chippendale G.M. 1991: Cold hardiness of larvae of the southwestern corn borer, Diatraea grandiosella. - Entomol. Exp. Appl. 58: 251-260.

Powell S.J. \& BALE J.S. 2004: Cold shock injury and ecological costs of rapid cold hardening in the grain aphid Sitobion avenae (Hemiptera: Aphididae). — J. Insect Physiol. 50: 277-284.

Qiang C., Du Y., CuI L., Zheng F. \& Lu M. 2008: Effect of rapid cold hardening on the cold tolerance of the larvae of the rice stem borer, Chilo suppressalis (Walker). - Agric. Sci. China 7: $321-328$.

QuinN P.J. 1985: A lipid-phase separation model of low-temperature damage to biological membranes. - Cryobiology 22: $128-146$.

Rezende E.L., Tejedo M. \& Santos M. 2011: Estimating the adaptive potential of critical thermal limits: methodological problems and evolutionary implications. - Func. Ecol. 25: 111-121.

Saeidi F., Moharramipour S. \& Barzegar M. 2012: Seasonal patterns of cold hardiness and cryoprotectant profiles in Brevicoryne brassicae (Hemiptera: Aphididae). — Environ. Entomol. 41: 1638-1643.

SALt R.W. 1966: Effect of cooling rate on the freezing temperatures of supercooled insects. - Can. J. Zool. 44: 655-659.

Santos M., Castan L.E. \& Rezende E.L. 2011: Making sense of heat tolerance estimates in ectotherms: lessons from Drosophila. - Funct. Ecol. 25: 1169-1180.

SHINTANI Y. \& IsHIKAWA Y. 2007: Relationship between rapid coldhardening and cold acclimation in the eggs of the yellow-spotted longicorn beetle, Psacothea hilaris. - J. Insect Physiol. 53: $1055-1062$. 
Sinclair B.J. \& Chown S.L. 2003: Rapid responses to high temperature and desiccation but not to low temperature in the freeze tolerant sub-Antarctic caterpillar Pringleophaga marioni (Lepidoptera, Tineidae). - J. Insect Physiol. 49: 45-52.

Slabber S., Worland M.R., Leinaas H.P. \& Chown S.L. 2007: Acclimation effects on thermal tolerances of springtails from sub-Antarctic Marion Island: indigenous and invasive species. - J. Insect Physiol. 53: 113-125.

Somme L. 1982: Supercooling and winter survival in terrestrial arthropods. - Comp. Biochem. Physiol. (A) 73: 519-543.

Sorensen J.G., Kristensen T.N. \& Loeschcke V. 2003: The evolutionary and ecological role of heat shock proteins. - Ecol. Lett. 6: 1025-1037.

Storey K.B. \& Storey J.M. 1988: Freeze tolerance in animals. Physiol. Rev. 68: 27-84.

Sung D.Y., Kaplan F., Lee K.J. \& Guy C.L. 2003: Acquired tolerance to temperature extremes. - Trends Plant Sci. 8: 179-187.

Teets N.M. \& Denlinger D.L. 2013: Physiological mechanisms of seasonal and rapid cold-hardening in insects. - Physiol. Entomol. 38: 105-116.
Terblanche J.S., Hoffmann A.A., Katherine A.M., Lea R., Peter C.L.R. \& ChOwn S.L. 2011: Ecologically relevant measures of tolerance to potentially lethal temperatures. - J. Exp. Biol. 214: 3713-3725.

Trivedi T.P. \& Rajagopal D. 1992: Distribution, biology, ecology and management of potato tuber moth, Phthorimaea operculella (Zeller) (Lepidoptera: Gelechiidae). - Trop. Pest Manag. 38: 279-285.

WANG X.H., QI X.L. \& KANG L. 2010: Geographic differences on accumulation of sugars and polyols in locust eggs in response to cold acclimation. - J. Insect Physiol. 56: 966-970.

Zheng X., Cheng W., Wang X. \& Lei C. 2011: Enhancement of supercooling capacity and survival by cold acclimation, rapid cold and heat hardening in Spodoptera exigua. - Cryobiology 63: $164-169$.

Received July 19, 2013; revised and accepted June 6, 2014 Prepublished online August 15, 2014 